https://doi.org/10.46344/jbino.2020.v09i5b.23

\title{
STUDY OF MOOTRAVAHASTROTAS IN VIEW OF MODERN SCIENCE
}

\author{
DR. SUNIL PANDIT GHONGADE1 * \& DR.A.M.DESHMUKH²
}

1.PG Scholar.DEPARTMENT OF ROGNIDAN AVUM VIKRITI VIGHYAN, CSMSS AYURVED COLLAGE AURANGABAD-431001. 2. Associate professor DEPARTMENT OF ROGNIDAN AVUM VIKRITI VIGHYAN,CSMSS AYURVED COLLAGE AURANGABAD-43I00I

\begin{abstract}
Strotas are innumerable channels or pathways which supply nourishment to dhatu and whole body. The Srotases are the whole channels of the body through which the materials needed for tissue building, nutrition, and other nutrients flow from one corner of the body to other.The holistic approach towards health and disease is the major strength of this science. It has gained a lot of acceptance and appreciation around the globe. To meet the expectations of the scientic community at every level, it is important that the system is explained to the modern world in the language and the terminology they understand. Urinary system of human body is explained in various ayurveda text books. Urine formation has a major role in human physiology.
\end{abstract}

KEYWORDS : Mutravaha Srotas, Anatomy \&pathophysiology of mutravaha srotas (urinary system ) 


\section{INTRODUCTION}

The holistic approach towards health and disease is the major strength of this science. Strotamsi stands for the inner delivery system of the body incorporation to that of circulatory system.Acharya Charka has defined it as "Sravnata Srotamsi" means the structure through which sravan takes place.Chakrapani has explained that Sravnata means sravan of rasadi dhatus, poshya. The Srotas means channels or system in which some tissues are formed, some material is metabolized, secreted or transported. In Ayurveda described Mutravaha Srotas in many aspects which include the embryology, etymology, anatomy, physiology etc. of urinary system. Sushrut Acharayas says "two Moolstana of Mutravaha srotas -Basti (urinary bladder) and Medra (urethra). Charaka Acharayas Charaka says two Moolstana of Mutravaha srotas - Basti (urinary bladder) and Vankshana (Iumbosacral region).

\section{AIMS AND OBJECTIVES :}

nutrition and building of the body.

\section{REVIEW OF LITERATURE :}

RACHANA SHARIR-Anatomical review anatomy of excretory system in Ayurvedic literature is very crude and miniature. Vrikka has been derived from vrikkadane, which means 'to take'. explaining the urinary system, Sushruta has not mentioned the vrikka in relation to the basti.

In the classics description of following anatomical structures are given relations to the Mutravaha srotas.

\section{BASTI:}

Basti is portrayed as one of the Ashaya, called 'mootrashaya'. is situated in the lower part of part of Nabhi. Acharaya Sushruta and Charaka both mentioned it aa Moolstana of Mutravaha srotas.

Sthana- According to Charak, basti is situated between the sthool-gud (rectum), mushka (scrotum), seevani (perineal raphe) and shukravaha nadi.Sushrut explained the situation of basti in gudasthi vivara (pelvic cavity) and is surrounded by different structures like nabhi, prishtha, kati, mushka, guda, vankshana, shepha. Embryological development: - During fetal life basti is derived from the maternal contribution. (Mattrajbhav).

\section{Anatomy of Urinary Bladder:}

Apex of the urinary bladder related to umbilicus by the median umbilicus ligament, the upper part of the base separated from the rectum by the retro vesical pouch and lower part is related to terminal part of the vasa deference.

Embryological development: - During fetal life basti is derived from the maternal contribution. (Mattrajbhav).

\section{VRIKKA-Kidney :}

The two kidneys are described as 'Pratyanga' and 'Koshthanga.are situated in lumber region in either sides in the posterior abdominal wall in "koshta".

Embryological Development: - Vrikka is also developed by the maternal contribution derived from the essence of "Rakta" and "Meda"

\section{GAVINI-Ureter:}

The ureter is one of the two uterine tubed that carries urine from the kidney to the 
bladder. Each ureter is about 10-12 inches long. Urine flows down part by gravity, but mainly by waves of contractions which passes several times per minutes through the muscles layers of urethral wall.

\section{Mutra Vaha Srotas Ayurved And modern view:}

A.Mutravaha Srotansi - These are the tabulated channels of kidney which have a clay pot like globular structure on their most proximal end. The process of nisyandana or Itration takes place here similar to as the clay pot mechanism explained in Ayurveda.

B.Mutra Vahi Dwe - two major hollow tubes or channels of urinary transport comparing the two ureters to ow the urine from both the kidneys to urinary bladder.

C.Mutra Srota i.e., the single main excretory tract i.e. urethra for exteriorization of urine.

\section{MUTRAVAHA NAADI :}

By Sushrut, mootravaha nidi are situated in between the amashaya, pakwashaya and basti.

These nadis have thousands of minute openings which are very small to visualizeThere function is mootra nisyandana (urine Itration), continuously whether in state of awakening or sleep, also drain the urine into basti and keep it moist or lled with urine in the same manner as river drain water into ocean.

\section{MUTRAVAHA DHAMNI :}

Basically three types of Dhamanis, depending upon the direction of their course,total 30 in numbers.Adhogami, depending upon the direction of their course, these are 10 in numbers.Adhogami dhamanis transport vata, mootra, purish, shukra,artava etc, downward the pelvic cavity. Two dhamanis which run toward mootra basti are termed as mootravaha dhamani. The function of mootravaha dhamani is said to be dharana and yapana of mootra and basti .

\section{MUTRAVAHA SIRA :}

Mootra vahini sira is available in Ashtanga Hridaya, where these are regarded as minute channels carrying the mootra to basti. These Siras are opening in the lateral side of the Basti and filled the Basti with Mutra continuously by the process of Nishyandan.

7.Mutra- Praseka or Mutra-Srota signies the urethra, mainly its penile part.

\section{Asthila:}

$A$ is the glandular structure found in male, around the bladder neck comparing the Prostate.

\section{KRIYA SHARIR-formation of urine}

Ayurvedic physiology encompasses the phenomena of urine formation right from the process of digestion of food and its absorption, especially absorption of water (precursor of urine) from the Pakwashaya.. Presumably Ayurvedic physiology presupposes that the process begins right from the gut and bloodcirculation because unless the water .. As we now know, the kidney is the most vascular organ of the body and it works as Iter for the blood. Thus the Ayurvedic physiology depicts three phases of urine formation namely;-

1) Udak i.e. water or precursor of urine. 2) Kleda i.e. the excreted bodily wastes.

3) Mutra i.e. the fully formed urine 


\section{SAMPRAPTI- pathology :}

The urinary disorders are solely pathological variant of srotas dysfunction and fractional disturbances of Dosha and Dushya. Common causes of deformity of urinary channels are drinking water, eating food and indulge in coitus, while there is urge of maturation .

The detailed classication of urinary dysfunctions in texts of ayurveda includes 20 syndromes or diseases namely, 8 Mutrakricchras i.e. dysureas and 13 kinds of Mutraghatas.Vagbhatt also includes 20 types of Prameha or Diabetic conditions in the province of Mutraroga or urinary diseases.

Mutrakricchra or Dysurias (8 types)

2)Ashmari or Urolithiasis (4 types)

3)Mutraghata i.e. Suppression and Retention of urine (13 types)

\section{DISCUSSION AND CONCLUSSION :}

It can be summarized that urinary diseases, which are considered as a morbid condition, are treatable with ayurveda. Our predecessors not only had a good knowledge about these diseases, but also they were aware of its clinical manifestations, pathogenesis and management modalities. The detailed anatomical and physiological vision of ayurveda in this regard is important, without which the better understanding about the treatment part can't be develop. The huge knowledge of urinary medicines and surgical procedures, present in Ayurveda can denitely bring out a revolutionary change in modern discipline of medical science. . Ayurvedic concept regarding anatomy of these structures is quite limited and very much scattered. Physiology of this system is also not very clear in Ayurvedic texts.

\section{REFERENCES :}

1. Sushruta, Sushruta Samhita, Ayurveda Tatrasandipika Hindi Commentary, by Kaviraja Ambika Datta Shastri.17th ed.2003, Su.Sharira. 4/30, Varanasi: Chaukhambha Sanskrita Sansthana.

2. Pt. Sarangdhar, Sharangdhar Samhita, Dipika Hindi Commentary, by Dr. Brahmanand Tripathi, Revised ed. 2013, Sarangdhar poorva khand 5/84, Varanasi: Chaukhambha Subharti Prakashan.

3. Sushruta, Sushruta Samhita, Ayurveda Tatvasandipika Hindi Commentary, by Kaviraja Ambika Datta Shastri.17th ed.2003, Su.Nidana 3/21-23, Varanasi: Chaukhambha Sanskrita Sansthana.

4. Sushruta, Sushruta Samhita, Ayurveda Tatvasandipika Hindi Commentary, by Kaviraja Ambika Datta Shastri.17th ed.2003, Su.Sharira 9/7, Varanasi: Chaukhambha Sanskrita Sansthana.

$5 . \quad$ Pt. Sarangdhar, Sharangdhar Samhita, Dipika Hindi Commentary, by Dr. Brahmanand Tripathi, Revised ed. 2013, Sarangdhar poorva khand 6/10-11, Varanasi: Chaukhambha Subharti Prakashan.

6. Sushruta, Sushruta Samhita, Ayurveda Tatvasandipika Hindi Commentary, by Kaviraja Ambika Datta Shastri.17th ed.2003, Su.Nidana 3/18-20, Varanasi: Chaukhambha

$7 . \quad$ Sanskrita Sansthana. Sushruta, Sushruta Samhita, Ayurveda Tatvasandipika Hindi Commentary, by Kaviraja Ambika Datta Shastri.17th ed.2003, Su.Sharira 5/47, Varanasi: Chaukhambha Sanskrita Sansthana.

8. Charaka, Charaka Samhita, Vidyotani Hindi Commentary, by Pandit Kashinath Shasrti. Revised edition 2007. 
Ch. Vimana 5/20., Varanasi:

Chaukhambha Sanskrita Sansthana.

9. Charaka, Charaka Samhita, Vidyotani Hindi Commentary, by Pandit Kashinath Shasrti. Revised edition 2007. Ch. Vimana 5/7. , Varanasi: Chaukhambha Sanskrita Sansthana

10. Sharangdhar Samhita Poorva khand $6 / 10$

11. Sharangdhar Samhita Tattva dipika Hindi, commentary by Dr. Brahamananda Tripathi, revised edition 2013. 